Revista Água Viva

ISSN 1678-7471

\title{
RESENHA DO LIVRO AMOR NENHUM DISPENSA UMA GOTA DE ÁCIDO: ESCRITOS DE CARLOS DRUMMOND DE ANDRADE SOBRE MACHADO DE ASSIS, DE HÉLIO DE SEIXAS GUIMARÃES
}

\section{REVIEW OF THE BOOK NO LOVE DISPISS A DROP OF ACID: CARLOS DRUMMOND DE ANDRADE 'WRITINGS ABOUT MACHADO DE ASSIS, BY HÉLIO DE SEIXAS \\ GUIMARÃES}

Wellington Vinicius da Cruz Godoi ${ }^{1}$

Recebido em: 11 abr. 2020.

Aceito em: 29 jun. 2020.

DOI 10.26512/aguaviva.v5i2.30720

O livro Amor nenhum dispensa uma gota de ácido: Escritos de Carlos Drummond de Andrade sobre Machado de Assis (2019), organizado por Hélio de Seixas Guimarães, doutor em Teoria e História Literária pela UNICAMP, brinda aos admiradores de Carlos Drummond de Andrade e Machado de Assis com uma reunião dos célebres textos do poeta Gauche sobre o Bruxo do Cosme Velho.

Ao apresentar a edição, Guimarães realça dois textos escritos por Carlos Drummond, separados por mais de trinta anos. O primeiro é de 1925, trata-se do "Sobre a tradição em literatura", em que o poeta de Itabira considerava Machado de Assis "um mestre de falsas lições, romancista tão curioso quanto monótono, um 'entrave à obra de renovação da cultura geral"” (GUIMARÃES, 2019, p. 09). Três décadas depois, em 1958, houve a publicação do poema “A um bruxo, com amor", composto principalmente por frases retiradas da obra de Machado - tal era a medida da admiração de Drummond.

Então é feita a questão motivadora da compilação: "O que teria se passado com Drummond entre 1925 e 1958, para mudar tão radicalmente de posição?” (GUIMARÃES, 2019, p. 10). A partir disso, Hélio de Seixas Guimarães traça o percurso percorrido por Drummond, do repúdio modernista às declarações de amor. No caminho, aborda temas como a apropriação do legado clássico pelo poeta, a difícil assimilação do passado pelos modernistas, as semelhanças da escrita em versos de Drummond com relação à prosa machadiana e, também,

\footnotetext{
${ }^{1}$ Graduado em Letras Português/Inglês pela Universidade Estadual do Norte do Paraná (UENP). Atualmente, é graduando em Letras Libras pela Faculdade Eficaz. E-mail: wellingtonvcgodoi@gmail.com
} 
as diferenças temáticas dos dois escritores - no escritor mais velho são as instituições que são arruinadas (política, religião, ciência), enquanto que no mais novo, "é a mitologia pessoal que vai sendo revisitada e caindo por terra" (GUIMARÃES, 2019, p. 22).

Por fim, apresenta as declarações de amor de Carlos Drummond de Andrade a Machado de Assis, a defesa pública contra a reedição sem discriminação de "inéditos" e contra a transladação dos restos mortais de Machado e sua esposa, Carolina, para o mausoléu a ser construído pela Academia Brasileira de Letras.

Refeitos os passos desse verdadeiro processo de conversão ao vazio, cabe ao leitor identificar por si mesmo, nos textos que seguem, esta que é certamente a principal afinidade entre esses dois escritores: o vício de escrever bem, muito bem, excessivamente bem (GUIMARÃES, 2019, p. 31).

A reunião dos textos de Carlos Drummond de Andrade sobre Machado de Assis em um único livro foi realizada, sem dúvida, com a presteza merecida por dois dos melhores escritores brasileiros. Tais escritos foram localizados na Fundação Casa de Rui Barbosa, no Rio de Janeiro, e foram selecionados nos casos de Machado de Assis ser o assunto principal ou em casos em que ele é importante para o argumento de Drummond, assinala o responsável pela organização, Hélio de Seixas Guimarães.

O projeto gráfico do livro (capa, contracapa, diagramação) obedece a um estilo moderno - como o feitio dos dois escritores homenageados -, no qual as fontes e cores são, ao mesmo tempo, simples e elegantes. O leitor ainda é presenteado com imagens da casa na Rua Cosme Velho onde Machadinho viveu com Carolina a maior parte de sua vida, de um trecho de seu testamento, entre outras imagens relacionadas a sua vida e obra.

Os 37 escritos estão organizados por ordem cronológica de sua primeira publicação em jornal, a exceção fica por conta do poema “A um bruxo, com amor”, que aparece em primeiro na compilação, embora não tenha sido o primeiro a ser publicado.

Em cada um dos textos pode-se notar a bela dicção drummondiana junto com a força de suas opiniões. No início, é de impressionar as antíteses evocadas pelo Gauche, afirmando, ao mesmo tempo, que ama certo escritor patrício (Machado de Assis), mas que o melhor a fazer é repudiá-lo, pois "Sua obra tem sido o cipoal em que se enredou e perdeu mais de uma poderosa 
individualidade, pela sutileza, pela perversidade profunda e ardilosa deste romancista tão curioso e, ao cabo, tão monótono" (DRUMMOND, 2019, p. 41).

Já nos derradeiros escritos, a redenção. Drummond defende os desejos e particularidades de Joaquim Maria, além de exaltar sua inteligência. Um bom exemplo pode ser captado na crônica "Entre Machado e Lima Barreto", na qual, após citar supostos adágios antigos, o poeta acaba confessando que eles foram assinados por Machado de Assis, que "O danado não morreu. Anda por aí, assuntando as coisas. Tenho vontade de saber o que ele acha da bomba (ou das duas bombas), do voto distrital e da sublegenda" (DRUMMOND, 2019, p. 145). Defendendo a postura de Drummond em relação ao pensamento sempre atual de Machado, pode-se citar, ainda, o seguinte trecho de uma crônica, em que ele defende que chegaria um tempo que as mulheres exerceriam todas as atividades políticas:

Eu quisera uma nação, onde a organização política e administrativa parasse nas mãos do sexo amável, onde, desde a chave dos poderes até o último lugar de amanuense, tudo fosse ocupado por essa formosa metade da humanidade. O sistema político seria eletivo. A beleza e o espírito seriam as qualidades requeridas para os altos cargos do Estado, e aos homens competiria exclusivamente o direito de votar (ASSIS, 2015, p. 28).

Salvo a graça que Machado faz em relação as qualidades requeridas para os cargos (beleza e espírito), pode-se entender que o Bruxo do Cosme Velho queria deixar clara sua defesa à participação feminina na política, algo ainda pouco comum em sua época, mas natural para o espírito visionário do escritor.

Dentre os textos, há de se destacar alguns dos que melhor assinalam a conversão do ódio ao amor de Drummond por Machado, são eles:

- A um bruxo, com amor: poema em que são enaltecidas as qualidades de Machado de Assis, composto principalmente por frases da obra dele, a exemplo do trecho: "E ficas mirando o ratinho meio cadáver/ com a polida, minuciosa curiosidade/ de quem saboreia por tabela/ o prazer de Fortunato, vivisseccionista amador" (DRUMMOND, 2019, p. 36), retirado do conto A causa secreta", publicado na coletânea Várias histórias, em 1896.

- Sobre a tradição em literatura: crônica em que critica duramente os autores tradicionais, considerando a necessidade de uma renovação da cultura geral. "Respeitamos a 
sua [de Machado de Assis] probidade intelectual, mas desdenhamos a sua falsa lição" (DRUMMOND, 2019, p. 41).

- Machado, não, O jazigo de Machado de Assis e Cemitério: defende a permanência dos restos mortais do escritor no jazigo onde foi enterrado ao lado de sua esposa, Carolina, a despeito das tentativas de levá-lo ao mausoléu a ser construído pela Academia Brasileira de Letras.

- [Uma gota de ácido]: o último escrito do livro é o que lhe dá o nome - atribuído por Guimarães -, em que Drummond comenta a literatura de Fialho de Almeida e Eça de Queiroz para, derradeiramente, se render a Machado de Assis:

[...] pela graça de Deus, cheguei cedinho a Machado de Assis. Deste não me separaria nunca, embora vez por outra lhe tenha feito umas má-criações. Justifico-me: amor nenhum dispensa uma gota de ácido. É mesmo o sinal menos que prova, pela insignificância e transitoriedade, a grandeza do sinal mais. Se me derem Machado na tal ilha deserta, estou satisfeito; o resto que se dane, embora o resto seja tanta coisa amorável (DRUMMOND, 2019, p. $152)$.

Hélio de Seixas Guimarães conseguiu realizar um trabalho importante para o momento pelo qual a literatura passa, demonstrando a admiração de um excelente escritor por outro excelente escritor, a influência de um sobre outro, uma tal coletividade entre gerações diferentes culminando para o bem da literatura. Afinal, o que seria da literatura brasileira sem Machado de Assis e Carlos Drummond de Andrade?

\section{REFERÊNCIAS}

ANDRADE, Carlos Drummond de; GUIMARÃES, Hélio de Seixas (org.). Amor nenhum dispensa uma gota de ácido: Escritos de Carlos Drummond de Andrade sobre Machado de Assis. São Paulo, SP: Três Estrelas, 2019. 160p.

ASSIS, Machado de. Obra completa em quatro volumes. Organização editorial de Aluizio Leite et al. 3. ed. São Paulo: Editora Nova Aguilar, 2015. 4 v. 1353p. 